\title{
IMPLEMENTATION OF A MOLECULAR SYSTEM FOR TRACEABILITY OF BEEF BASED ON MICROSATELLITE MARKERS
}

\author{
Ricardo Felmer D. ${ }^{*}$, Boris Sagredo D. ${ }^{2}$, Renato Chávez R. ${ }^{1,3}$, Sergio Iraira H. ${ }^{2}$, \\ Carolina Folch M. ${ }^{2}$, Lorena Parra G. ${ }^{1}$, Adrián Catrileo S. ${ }^{1}$, and Manuel Ortiz L. ${ }^{4}$
}

\section{A B S T R A C T}

Animal products traceability has acquired considerable importance as a security measure in EEC member countries since the food crisis of the mid-nineties. This has led to reinforcing the capacity to manage cattle product quality, with traceability emerging as the main tool to prevent risks to product security and quality as demanded by consumers in developed countries. The practical application of a traceability system for beef, based on molecular markers requires the election of a panel of microsatellites, as well as the optimization of methods of sampling and DNA analysis. In this work, a traceability system for beef based on a panel of 10 microsatellites markers was implemented. Different biological samples were evaluated, such as hair, blood, tissue and meat. Hair samples were the most suitable because they are easy to obtain and to manipulate, and have a low storage cost; whereas in the food processing chain, meat samples were the most suitable due to the facility of obtaining from the maturation room. The traceability system was evaluated in a meat processing plant, confirming traceability of 150 samples of hair with their respective meat counterparts with a $100 \%$ of certainty, demonstrating the reliability of the developed method. The implemented system is an important contribution since it allows for ensuring the quality of animal products, and can be used as a tool to certify conventional traceability systems. This would allow for increasing the competitiveness of this sector and generating greater confidence among consumers.

Key words: traceability, microsatellites, individual identification, beef.

\section{INTRODUCTION}

Increased global trade and the need to ensure the safety and quality of food products imposes the demand on exporting countries of ensuring the origin of their products, in order to avoid the repetition of problems experienced in Europe in the 1990s with the diffusion of pathologies such as bovine spongiform encephalopathy (BSE) and scrapie in ovines, foot and mouth disease and classical swine fever. As well, there are requirements to detect hormones, steroids, antibiotics, pesticides, lead and/or pathogens in foods and products of animal origin. At the same time, the increased risk of bio-terrorist attacks is also considered a food safety factor, mainly in the United States and the EEC. As a result, main importing countries have developed a series of regulations and measures to control these risks to human health in order to ensure consumer confidence. The direct consequence on exporting countries has been the establishment of policies for the individual identification and follow-up of animals and their products through the application of new technologies adapted to the needs of current global trade, with traceability being one of the main results of these policies (Council of the European Communities, 2000).

In general, traceability is a set of technical actions, measures and procedures that allow for identifying and registering a product from its origin until the end of the commercial chain (Fernández, 2002). In the case of meat, this means follow-up throughout the production chain, from the birth of the animal, its raising and production practices in the feedlot, transport, slaughter, and final sale of meat products. This process should ensure the

\footnotetext{
${ }^{1}$ Instituto de Investigaciones Agropecuarias, Centro Regional de Investigación Carillanca, Casilla 58-D, Temuco, Chile. E-mail: rfelmer@inia.cl_*Corresponding author.

${ }^{2}$ Instituto de Investigaciones Agropecuarias, Centro Regional de Investigación Remehue, Casilla 24-D, Osorno, Chile.

${ }^{3}$ Current address: Universidad de Santiago de Chile, Facultad de Química y Biología, Casilla 40, Correo 33, Santiago, Chile.

${ }^{4}$ Universidad Austral de Chile, Centro de Inseminación Artificial, Casilla 567, Valdivia, Chile.

Received: 16 August 2007. Accepted: 23 November 2007.
} 
identity of the product as a means of verifying its safety and quality, such that in the event of any problem, it is possible to trace the product through the productive chain back to the farm where the animal was born.

One of the main requirements of traceability is the implementation of an animal identification system. In this regard, several systems, both biometric and nonbiometric, are currently in application or development (Felmer et al., 2006). Among the biometric systems are nose printing, retinal scanning and DNA tracing (Masahiko et al., 2001; Chávez et al., 2004; Vázquez et al., 2004). Among the non-biometric methods are tattoos, conventional and freeze branding, tagging, electronic chips, ruminal boluses, transponders, etc. (Caja et al., 2000; Ribó et al., 2001; Conill et al., 2002).

In Chile, the Servicio Agrícola y Ganadero (SAG) has an official individual identification device (OIID), which is a yellow tag with a unique number for each head of cattle (SAG, 2006). While this system of identification has the advantages of being easy to read, durable and harmless, the tags are removed from the animal at the meat processing plant. It is desirable therefore to have a certification system that can ensure post-mortem animal traceability to avoid errors in identification, fraud or adulteration after slaughter of the animal. A good alternative for animal identification is DNA, which remains present in all tissue cells of both live animals and any product derived from the animal. In this manner, DNA represents the best and most inviolable natural marker to be used in tracing meat products (Vázquez et al., 2004).

Except for monozygotic twins and cloned animals, genetic animal identification is based on the principle that all the individuals of a given population differ among themselves in their DNA (Cunningham and Meghen, 2001), making it feasible to use a genetic test with molecular markers to establish these differences (Lodish et al., 1995). Microsatellites have become the molecular tool of choice for genetic analysis and animal identification studies because of three fundamental characteristics: i) they can be segregated according to a hereditary pattern; ii) they can be found distributed throughout the genome, and iii) they are composed of repeated conserved units (two to six base pairs), that vary in the number of repetitions (Tautz, 1989; Visscher et al., 2002). This last characteristic allows for finding a wide diversity of sizes in the microsatellites analyzed, which can be detected by diverse molecular biology techniques currently available (Blott et al., 1999).
The objective of this study was to implement a system of molecular traceability for beef in Chile, using a panel of molecular markers (microsatellites) specific to bovines and identify the best biological samples to use for this system, to ensure the origin of beef products and certify the adequate functioning of current tracing systems.

\section{MATERIALS AND METHODS}

\section{Biological samples}

The study was carried out between 2005 and 2006 . Samples were collected from around 200 animals belonging to different herds throughout the Araucania ( $\left.38^{\circ} 46^{`} \mathrm{~S}, 72^{\circ} 38^{`} \mathrm{~W}\right)$ and the Lake Regions (43⒊ S, $\left.73^{\circ} 4^{\prime} \mathrm{W}\right)$, Chile. The different tissue samples were collected from feedlots, meat processing plants and rendering areas. The samples of hair (hair follicles), biopsied ear tissue and blood were obtained in the farms in accordance with the previously described methods (Chávez et al., 2004). The counter-samples of carcass meat were obtained from processing line (maturation area) or from rendering areas of the meat processing plants of Carnes Ñuble (Chillán) and GANASUR (Osorno) (Chávez et al., 2004).

\section{Purification of DNA from biological samples and microsatellite analysis}

DNA purification based on samples of hair, tissue and/ or blood was carried out according to the previously described methods (Chávez et al., 2004; Folch et al., 2004). Ten microsatellite markers were used, which were those included in the StockMarks for Cattle ${ }^{\circledR}$ (Applied Biosystems, Foster, California, USA). These markers were selected because of the large amount of polymorphic information content (PIC) they provide and because they are recommended by the International Society of Animal Genetics (ISAG, Oxford, United Kingdom) as standard markers for bovine comparison. These markers were distributed among 3 multiplex reactions, in accordance with the amplification conditions described in Chávez et al. (2004) and Folch et al. (2004). The PCR products obtained were analyzed with an automatic sequencer (ABI PRISM 310, Applied Biosystems, Foster, California, USA) in accordance with the manufacturers instructions, or using polacrylamide gels and silver staining (Folch et al., 2004).

\section{Assessment of the discriminating power of the selected microsatellites}

To assess the power of the microsatellites to discriminate among different individuals, 52 and 63 animals were 
sampled, from the Black Friesian (BF) and Red Friesian (RF) breeds, respectively, to which the genotype of the 10 microsatellite markers were determined. The BF group was a milking herd at of the Agricultural Research Institute (INIA), Carillanca Regional Research center in Temuco. The RF samples were young bulls from three groups of Red Friesian from the Lake Region. The allelic frequency of these animals was determined by directing counting of the alleles obtained. The numbers of allelic combinations and unique genotypes were obtained for each marker. According to the allelic frequency, the polymorphic information content (PIC) was determined in the different populations for each of the markers, in accordance with the formula of Botstein et al. (1980). As well, the expected values of confusion $(\mathrm{Cj})$ and discrimination $(\mathrm{Dj})$ index and the possible pairs to be confused $(\mathrm{Xj})$ were determined in accordance with Tessier et al. (1999), and the respective observed values were obtained by grouping analysis according to Mathias et al. (2007).

\section{Evaluation of traceability in a meat processing plant}

To evaluate the molecular traceability system in a meat processing plant (Figure 1), 150 animals were sampled in different farms in the Araucania and Lake Regions, whose carcasses would enter the slaughterhouses FRIGOSOR and Carnes Nuble, since they corresponded to herds PABCO A (Officially Certified Farms), whose meat products are destined to the EEC markets. The animals were sampled at the farms (removing hair follicles) at the same time as the official individual identification device (OIID) was placed. The counter-samples of carcass meat were obtained after the animals were taken to the slaughtering plant, where they were identified by the respective tag number and the code number assigned by the processing plant.

\section{RESULTS AND DISCUSSION}

\section{Amplification of microsatellites}

Figure 2 shows the results of the microsatellite analysis in multiplex and visualization using two analysis systems. The first consists of electrophoresis detection in polyacrylamide gels and silver staining. With this technique, the distinct alleles of a microsatellite migrate within a polyacrylamide matrix with the application an electric charge, separating according to size differences. In this way, employing an appropriate molecular size standard, it is possible to establish the pattern of polymorphism and DNA molecules that allows for identifying the analyzed samples (Folch et al., 2004). Figure 2A, for example, shows the genetic identity of three animal samples analyzed with the microsatellites INRA 23, TGL122 and TGLA 227. As can be seen in the figure, the three samples have their own band profiles, confirming that they are from different animals, even when some alleles are shared (i.e., alleles of microsatellite TGLA 227 in samples 1 and 3).

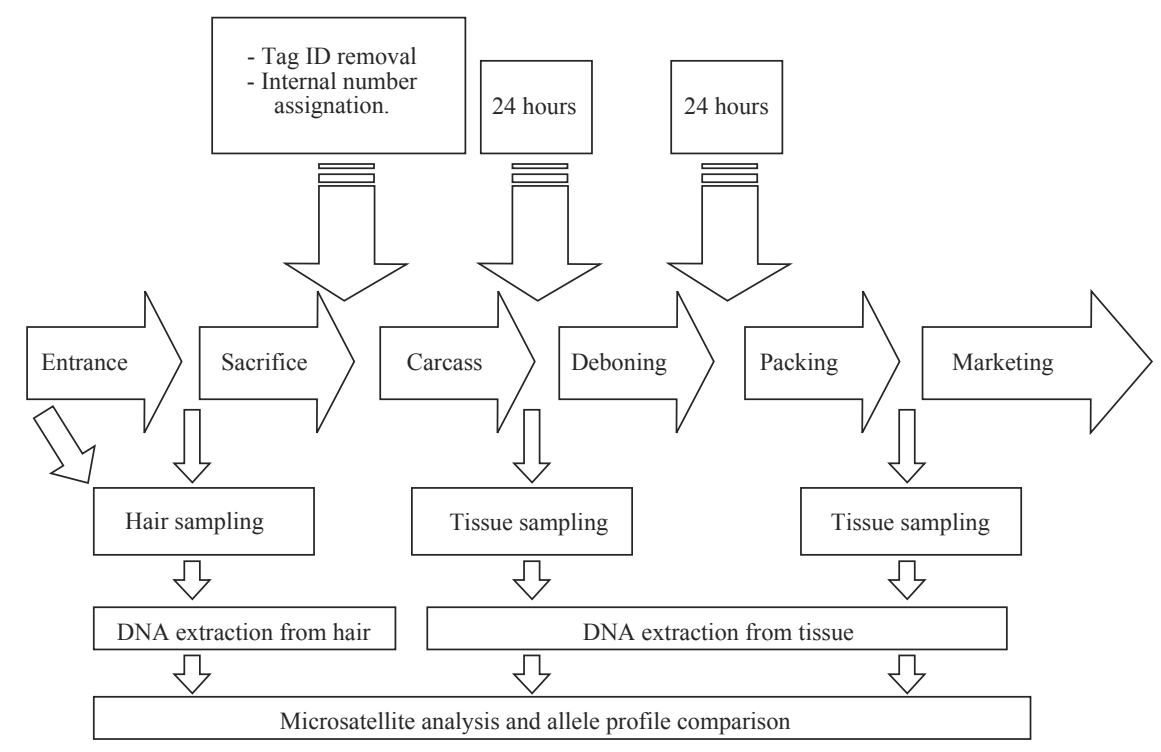

Figure 1. Flow chart of a meat processing plant and details of sampling and analysis. 
A)

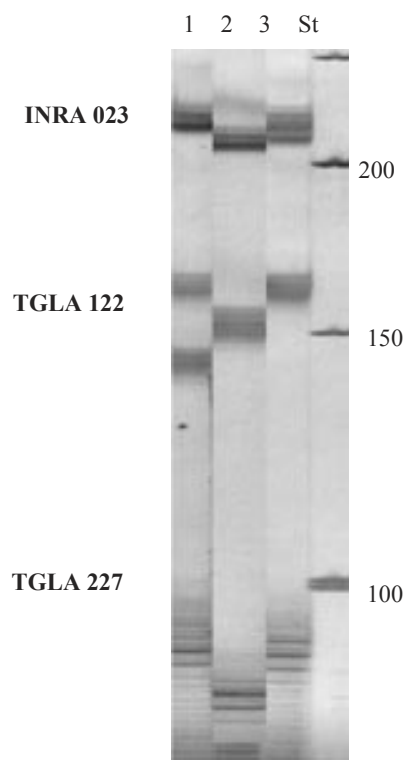

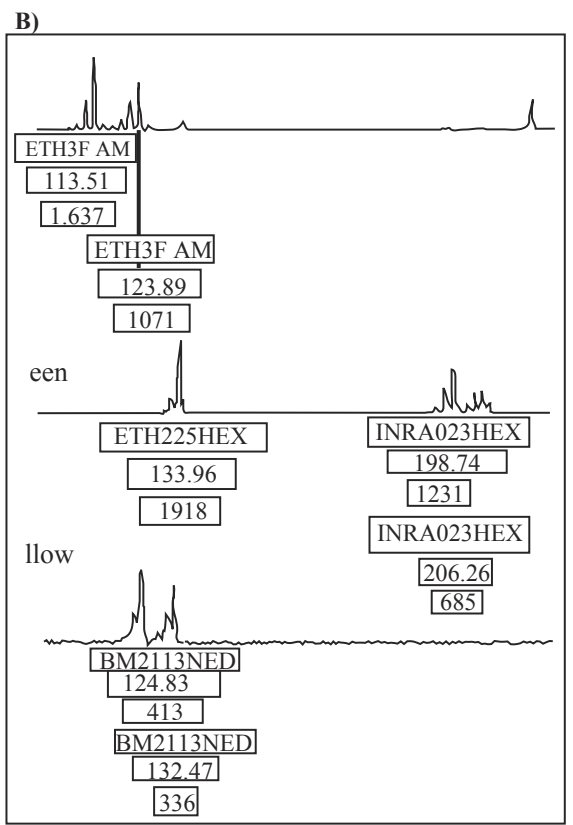

Figure 2. DNA fragments obtained by means of multiplex PCR reactions. A) Fragment analysis of three animal samples (1-3) separated by means of silver stained polyacrylamide gel, using molecular markers INRA 023, TGLA 122 and TGLA 227; ST: molecular size standard. B) Fragment analysis of a tissue sample by means of their fluorescence with an automatic sequencing machine using molecular markers ETH3, ETH225, INRA23 and BM2113.

The second detection method assessed was capillary electrophoresis in an automatic sequencer (Figure 2B). This system uses oligonucleotides marked with distinct fluorescent chemical compounds, which, after being amplified by PCR, can be analyzed simultaneously by the detector of the sequencer. As well as discriminating DNA fragments by size, this system can identify them by the fluorescence emitted by the fluorphore. In this way, the method allows for a greater degree of flexibility to establish the multiplex, as well having greater velocity and automation (Chávez et al., 2004). Figure 2B shows the example of an electropherogram obtained in the automatic sequencer. In this case, the multiplex reaction included four microsatellite markers (ETH3, ETH225, INRA23 and BM2113). The size of the alleles of these markers is directly assigned by the equipment, in comparison to an internal size standard that is run together with the samples. In this way, the optimal conditions were defined for using the 10 microsatellites in three multiplex reactions, both for the automatic sequencer and the system of polycrylamide gels (Chávez et al., 2004; Folch et al., 2004).

\section{Biological sample}

The application of a molecular traceability system requires sampling from live animals and products derived from them (meat) at different stages in the production chain, from calf, the animal carcass and finally meat product (Table 1). In this study, different biological samples of the animal were assessed at distinct stages in the productive chain, finding that in general all of the samples can be used for analysis (Table 2). Nevertheless, there are a number of factors that should be considered at the moment of selecting the sample to be used. In the case of a sample from a live animal (pre-mortem) it is important to consider storage, among other things, given that the sample should remain stored until the animal is slaughtered. The method of DNA extraction for the sample is another important factor to consider. Although it is possible to obtain DNA from the saliva, the low hygiene of this type of sample, added to the difficulty of obtaining it, makes this method impractical (data not shown). In the case of blood, a major disadvantage is in its handling, given that it is necessary to take the sample from the animal, which makes sampling very laborious if there are a large number of animals. Besides, this procedure is restricted to veterinarians in some countries, such as England and Scotland (Bruce Whitelaw, Roslin Institute, Scotland, personal communication). Finally, these samples must be stored refrigerated until being used to avoid coagulation. Although the results of this study confirmed the potential utility of blood (Table 2), there is also the disadvantage that many components 
Table 1. Characteristics of sampling and storage of different biological samples assessed.

\begin{tabular}{|c|c|c|c|}
\hline Sample & Sampling & Storage & $\begin{array}{c}\text { Observations } \\
\end{array}$ \\
\hline Hair & $\begin{array}{l}\text {-Use flat end pliers. } \\
\text {-Remove hairs from the animal's back. } \\
\text {-Pull against the hair growth. } \\
\text {-Obtain visible hair follicles. }\end{array}$ & $\begin{array}{l}-4{ }^{\circ} \mathrm{C} \text { or room } \\
\text { temperature }\end{array}$ & $\begin{array}{l}\text { Use black or white hairs (avoid using } \\
\text { red or brown hairs). } \\
\text { If wet, dry hairs at } 37^{\circ} \mathrm{C} \text { for } 24 \mathrm{~h} \text {. }\end{array}$ \\
\hline Biopsy & -Remove with a punch from the ear. & $\begin{array}{l}-4^{\circ} \mathrm{C} \text { if used } \\
\text { immediately, if } \\
\text { not, store at }-20 \\
{ }^{\circ} \mathrm{C} \text {. }\end{array}$ & $\begin{array}{l}\text { A special punch is required, type } \\
\text { Biopsytec. }\end{array}$ \\
\hline Blood & $\begin{array}{l}\text {-Use EDTA as an anti-coagulant. } \\
\text {-Obtain by coccygeal puncture. } \\
\text {-Agitate the sample immediately. }\end{array}$ & -4 or $-20^{\circ} \mathrm{C}$ & Hemolysis should be avoided. \\
\hline $\begin{array}{l}\text { Counter- } \\
\text { sample }\end{array}$ & $\begin{array}{l}\text {-Obtain from a mature carcass in } \\
\text { maturation room, from a muscle offering } \\
\text { easy access. A punch system can be } \\
\text { used to obtain a piece of tissue. }\end{array}$ & $-20^{\circ} \mathrm{C}$. & $\begin{array}{l}\text { The production record should be } \\
\text { requested. }\end{array}$ \\
\hline
\end{tabular}

Table 2. Analysis of microsatellites by means of multiplex reactions from different biological samples from the same animal.

\begin{tabular}{|c|c|c|c|c|c|c|c|c|c|c|c|}
\hline \multicolumn{2}{|c|}{ Sample } & \multicolumn{4}{|c|}{ Multiplex 1} & \multicolumn{3}{|c|}{ Multiplex 2} & \multicolumn{3}{|c|}{ Multiplex 3} \\
\hline & & ЕТН3 & TGLA122 & TGLA227 & BM1824 & ETH10 & ЕTH225 & BM2113 & INRA23 & SPS115 & TGLA126 \\
\hline \multirow{8}{*}{1} & \multirow{2}{*}{$\mathrm{H}$} & 114 & 140 & 83 & 180 & 214 & 138 & 128 & 198 & 242 & 125 \\
\hline & & 118 & 148 & 91 & 182 & 216 & 144 & 134 & 212 & 242 & 125 \\
\hline & \multirow{2}{*}{ B } & 114 & 140 & 83 & 180 & 214 & 138 & 128 & 198 & 242 & 125 \\
\hline & & 118 & 148 & 91 & 182 & 216 & 144 & 134 & 212 & 242 & 125 \\
\hline & \multirow{2}{*}{$\mathrm{C}$} & 114 & 140 & 83 & 180 & 214 & 138 & 128 & 198 & 242 & 125 \\
\hline & & 118 & 148 & 91 & 182 & 216 & 144 & 134 & 212 & 242 & 125 \\
\hline & \multirow{2}{*}{$\mathrm{B} 1$} & 114 & 140 & 83 & 180 & 214 & 138 & 128 & 198 & 242 & 125 \\
\hline & & 118 & 148 & 91 & 182 & 216 & 144 & 134 & 212 & 242 & 125 \\
\hline \multirow{8}{*}{2} & \multirow{2}{*}{$\mathrm{H}$} & 116 & 140 & \multirow{2}{*}{ n.c. } & 180 & 216 & 142 & 130 & \multirow{2}{*}{ n.c. } & 248 & 117 \\
\hline & & 124 & 160 & & 182 & 222 & 144 & 134 & & 248 & 125 \\
\hline & \multirow{2}{*}{ B } & 116 & 140 & 93 & 180 & 216 & 142 & 130 & 198 & 248 & 117 \\
\hline & & 124 & 160 & 93 & 182 & 222 & 144 & 134 & 206 & 248 & 125 \\
\hline & \multirow{2}{*}{$\mathrm{C}$} & 116 & 140 & 93 & 180 & 216 & 142 & 130 & 198 & 248 & 117 \\
\hline & & 124 & 160 & 93 & 182 & 222 & 144 & 134 & 206 & 248 & 125 \\
\hline & \multirow{2}{*}{ B1 } & 116 & 140 & 93 & 180 & 216 & 142 & 130 & 198 & 248 & 117 \\
\hline & & 124 & 160 & 93 & 182 & 222 & 144 & 134 & 206 & 248 & 125 \\
\hline \multirow{8}{*}{3} & \multirow{2}{*}{$\mathrm{H}$} & 114 & 146 & 81 & 180 & 214 & 144 & 130 & 200 & 242 & 117 \\
\hline & & 114 & 146 & 93 & 188 & 216 & 144 & 130 & 206 & 246 & 117 \\
\hline & \multirow{2}{*}{ B } & 114 & 146 & 81 & 180 & 214 & 144 & 130 & 200 & 242 & 117 \\
\hline & & 114 & 146 & 93 & 188 & 216 & 144 & 130 & 206 & 246 & 117 \\
\hline & \multirow{2}{*}{$\mathrm{C}$} & 114 & 146 & 81 & 180 & 214 & 144 & 130 & 200 & 242 & 117 \\
\hline & & 114 & 146 & 93 & 188 & 216 & 144 & 130 & 206 & 246 & 117 \\
\hline & \multirow{2}{*}{ B1 } & 114 & 146 & 81 & 180 & 214 & 144 & 130 & 200 & 242 & 117 \\
\hline & & 114 & 146 & 93 & 188 & 216 & 144 & 130 & 206 & 246 & 117 \\
\hline
\end{tabular}

H: hair; B: biopsy from the ear; C: piece of carcass meat; Bl: blood; n.c.: not considered. Refers to samples that did not amplify or whose products from amplification could not be read correctly by the sequencer. 
of the sample, including hemoglobin, inactivate the DNA polymerase required for the amplification of microsatellites and possibly affecting the reproducibility of the results (Panaccio and Lew, 1991).

The animal tissue biopsy (ear) proved to be a good option (Table 2). Some European companies have developed a punch system that allows for obtaining tissue samples from the ear at the same time as the tag is applied; one such commercial system is called Biopsytec (Rheinbach, Germany). The advantage of this system is that the sample is encapsulated in a labeled and inviolable container, remaining sealed until use in the laboratory. As well, these devices can be of a button or palette type, adjusting to the tracing requirements of each country. However, a disadvantage of this system is its higher cost.

Given the above, hair appears to be a better option, given the lower cost, easy collection and storage. The advantage of hair samples is that they can be stored in paper bags at room temperature or in refrigeration $\left(4^{\circ} \mathrm{C}\right)$. However, there are some important points to be taken into consideration when using hair samples, such as avoiding sampling on rainy days, given that moisture can interfere in laboratory analysis (data not shown). As well, a large number of samples should be obtained to choose from, with the aim of having at least 10 to 15 visible hair follicles. Finally, to the extent that it is possible, black hairs should be obtained given that this color facilitates observation and subsequent handling in the laboratory. Red hairs should be avoided, given that in this study it was observed that these contain pigments that color the solutions and can inhibit the PCR reaction. This situation is seen for example in the analysis of hair samples from animal of the Hereford breed, in which at least two microsatellites could not be amplified in this sample (Table 2, animal $\mathrm{N}^{\circ} 2$ ). This did not, however, represent a problem in determining the correlation of the samples as it was possible to make the determination with the information provided by the other microsatellites analyzed. In this regard, in the case of animals from Hereford or Simmental breeds, it should be taken a greater number of hair samples from which to choose the best for analysis.

In the case of post-mortem samples, while bone and fat can also be used, the methods of DNA purification for these types of samples are much more laborious. Obtaining a piece of bone or tooth also supposes a higher degree of difficulty. The best sample is a piece of muscle from the carcass, such as the Longissimus dorsi muscle at the 12-13 ribs, or another muscle offering easy access, sample that can be taken in the maturation room, which is ideal for several reasons: minimal people movement, there is no danger of contamination of biological samples from other animals, and most importantly the factor time. A slaughtered carcass usually mature in $48 \mathrm{~h}$, which provides 2 days between slaughter and rendering to take the sample. It is important to note that in Chile, processing plants slaughter animals in groups and not individually. Consequently, it is not possible to evaluate samples after rendering. This is a relevant aspect to consider in relation to post-processing traceability, for example in sampling at the point of sale (supermarkets and meat stores), as is done in some countries, which have had to implement a system of individual rendering.

In conclusion, considering easy sampling, DNA extraction, storage and delivery to laboratory, the best samples to use in a system of molecular traceability of meat are hair, as an initial sample in the live animal, and a piece of carcass meat as the countersample, obtained from the maturation room at the slaughterhouse.

\section{Discriminating power of the system}

An important characteristic of the molecular traceability system is its capacity to discriminate among animals with a high degree of genetic similarity. This means that the technique should be able to identify individual samples, even if they come from close relatives, for example, siblings, which in turn belong to a population in which there is a high degree of inbreeding, a situation that is very common in bovine production. Table 3 shows the main characteristics of the markers in the two groups of bovines analyzed, black Frisian (BF) and red Frisian (RF), with 52 and 63 animals, respectively. These animals are European breeds introduced to Chile more than 100 years ago (Mujica, 2005).

As can be seen in Table 3, all of the markers showed a high degree of polymorphism, with the number of alleles varying from 4 to 9 and 4 to 12 , for the BF and $\mathrm{RF}$ groups, respectively. This data is in agreement with that obtained with these microsatellites in other bovine breeds (Bedoya et al., 2001; Zamora et al., 2004). As well, each marker was evaluated according to the value of the polymorphic information content (PIC). This parameter is often used to measure the microsatellites capacity to discriminate among different individuals and their values can vary between 0 and 1 , indicating a greater level of polymorphism or variation when the value is closer to 1 . In accordance with this, the 


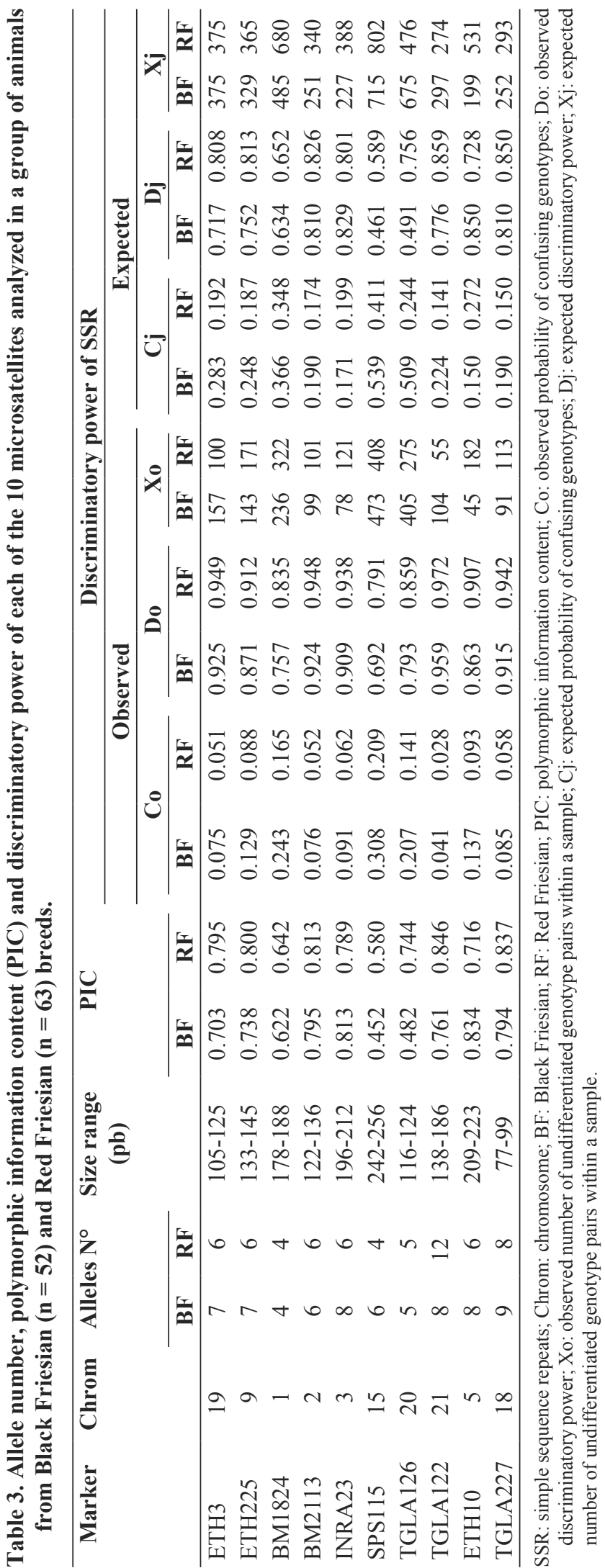

discriminatory power found for these microsatellites was generally high, the PIC index varying between 0.452 and 0.834 and between 0.580 and 0.846 and the expected discrimination index $(\mathrm{Dj})$ between 0.461 and 0.850 and between 0.589 and 0.859 , for the BF and RF groups, respectively (Table 3 ). It is important to note that the estimation of the expected discriminatory power $(\mathrm{Dj})$ of each microsatellite, the same as the value of the PIC, depends directly on the allelic frequency (Tessier et al., 1999), consequently the two values are practically identical, which was confirmed by the results obtained (Table 3 ).

The values of the observed discrimination index (Do) vary between 0.692 to 0.959 and 0.791 and 0.972 , for the BF and RF groups, respectively (Table 3). In general, the observed values for this index (Do) were higher than those expected (Dj), which would tend to decrease as the number of animals included in the analysis increases. In the same way, the probability of confusion of observed genotypes (Co) was lower than expected $(\mathrm{Cj})$ in both groups, with Co ranges that varied from 0.041 to 0.308 for $\mathrm{BF}$ and from 0.028 to 0.209 for RF, respectively (Table 3). In all the cases, it was confirmed that the observed values for the 10 microsatellite markers had a better power of resolution than the expected values. This can be seen clearly when comparing the number of pairs $(\mathrm{X})$ that can be confused, between the observed $(\mathrm{Xo})$ and expected values $(\mathrm{Xj})$, for the BF and RF populations (Table 3).

With regard to the combined use of all the markers for animal identification, the expected and observed values indicate that it would be necessary to analyze a population of 5678 and 869608 animals to find a pair of individuals that can be confused $(\mathrm{X}=1)$ among the BF and RF populations, respectively. In other words, the possibility of confusing a pair of individuals that share the same pattern of markers is 0.00018 and 0.00000115 , respectively. If we consider that the major difficulty in discriminating individuals occurs when comparing individuals from the same herd and that the breeding practices of the analyzed populations of BF and RF is similar to the breeding practices with the majority of herds in Chile, where a moderate degree of inbreeding is expected (data not shown), the results obtained on the discriminating power of these markers can be extrapolated to the rest of the bovine population in Chile, allowing for the application of this system for analysis of any bovine population in the country. 


\section{Evaluation of traceability in a meat processing plant}

Without doubt the processing of animals in meat packing plants represents the most critical point of the traceability system, given that the original identification system provided by the tag is replaced by a code number in the processing plant. This number must be maintained to identify all the cuts derived from the same carcass. Considering the high degree of certainty $(>99.9 \%)$ of the identification methods based on DNA polymorphism, they represent an excellent tool for verification of the animal identification systems adopted by meat processing plants. The microsatellites analysis of 150 hair samples and their respective counter-samples of carcass meat confirmed the traceability of the same with $100 \%$ certainty (Table 4 ).

The analysis of the sizes generated by the microsatellites of all the samples assessed showed complete coincidence between the hair samples and their respective counter-samples of carcass meat. A low signal in microsatellites was obtained only in very specific cases, but this did not interfere with the analysis and correlation of the samples (Table 4). In these cases the problem was observed in hair samples that required more care in their sampling and analysis. These results indicate that, under the conditions analyzed, the technique can identify samples from the same animal with absolute certainty, demonstrating the potential of the technology implemented for certifying conventional traceability systems already applied in the country, thus representing an important element in quality control.

For the practical application of this system, the samples to be evaluated should be obtained randomly from different points throughout the production chain, from live animals in farms, carcasses at slaughter houses, meat in rendering areas and in supermarkets and meat stores. The method implemented allows for the initial sampling of hair in an economic and convenient way, given that the producer or veterinarian can do the sampling at the same time as marking the animals with the official OIID. These samples can be easily sent in a envelope to the laboratory, where can be stored until analysis, with no more cost to the laboratory or the entity responsible for the quality control system. In the case of the countersample, the sampling can be done directly by personal of the packing plant or quality control personnel hired specifically for that role, and do not require important changes in current industrial procedures. In this way, DNA analysis should be done with random samples to control the traceability of an animal from the farm to the processing industry, or for complain investigation or any other case where it is required.

It is important to note that analysis costs can be reduced considerably (at least by $40 \%$ ) if a directed identification protocol is implemented, that is, not at random, but rather using samples and counter-samples that are assumed to be identical. In this case, the analysis can be carried out with only three highly polymorphic microsatellites, which would be sufficient to ensure the same origin of a sample, thus with a directed identification protocol the probability given by three microsatellites ( 1 in 1000 coincidence at random) is very high (Vázquez et al., 2004). However, if the analysis is made to identify a meat sample against a group, which would be the current situation in meat processing plants in Chile, the analysis necessarily should include a higher number of markers, such as the ten evaluated in this work.

The implemented system is an important contribution to the cattle sector of the country, since it ensures the quality of the products to be used as certification tools in conventional traceability, thus increasing the competitiveness of this sector and generating greater confidence in national and international consumers who are increasingly demanding guarantees of quality of the products they buy.

\section{CONCLUSIONS}

The best biological samples determined for the traceability system was the hair, with carcass meat as counter-samples, because of facility of obtaining, handling and storing cost.

The implemented traceability system allowed the confirmation of the traceability of 150 hair samples with their respective meat counter-samples, with $100 \%$ certainty, demonstrating the reliability of the method developed.

The implemented system is an important support to the cattle sector of the country, given that it can ensure the origin of beef products and be used as a tool to certify conventional traceability techniques.

\section{ACKNOWLEDGEMENTS}

This work was developed thanks to the funding support of FDI-CORFO, Project 03C9AT-01. We are grateful to Dr. Armand Sánchez of the Universidad Autónoma de Barcelona for technical support in the initial selection 
Table 4. Analysis of the traceability of six animals in a meat processing plant.

\begin{tabular}{|c|c|c|c|c|c|c|c|c|c|c|c|}
\hline \multirow{2}{*}{\multicolumn{2}{|c|}{ Sample }} & \multicolumn{4}{|c|}{ Multiplex 1} & \multicolumn{3}{|c|}{ Multiplex 2} & \multicolumn{3}{|c|}{ Multiplex 3} \\
\hline & & ETH3 & TGLA122 & TGLA227 & BM1824 & ETH10 & ЕTH225 & $\overline{B M 2113}$ & INRA23 & SPS115 & TGLA126 \\
\hline \multirow{4}{*}{1} & \multirow{2}{*}{$\mathrm{H}$} & 123 & 140 & 81 & 181 & 211 & 133 & 124 & 201 & 252 & 121 \\
\hline & & 123 & 152 & 99 & 183 & 215 & 141 & 128 & 207 & 256 & 121 \\
\hline & \multirow{2}{*}{$\mathrm{C}$} & 123 & 140 & 81 & 181 & 211 & 133 & 124 & 201 & 252 & 121 \\
\hline & & 123 & 152 & 99 & 183 & 215 & 141 & 128 & 207 & 256 & 121 \\
\hline \multirow{4}{*}{2} & \multirow{2}{*}{$\mathrm{H}$} & 113 & 140 & 99 & 181 & 213 & 141 & 122 & 205 & 256 & 121 \\
\hline & & 121 & 172 & 99 & 183 & 215 & 141 & 124 & 215 & 256 & 121 \\
\hline & \multirow{2}{*}{$\mathrm{C}$} & 113 & 140 & 99 & 181 & 213 & 141 & 122 & 205 & 256 & 121 \\
\hline & & 121 & 172 & 99 & 183 & 215 & 141 & 124 & 215 & 256 & 121 \\
\hline \multirow{4}{*}{3} & \multirow{2}{*}{$\mathrm{H}$} & 113 & 174 & \multirow[b]{2}{*}{$\mathrm{nc}$} & 183 & 213 & 141 & 122 & \multirow[b]{2}{*}{$\mathrm{nc}$} & 248 & 121 \\
\hline & & 117 & 182 & & 183 & 215 & 143 & 132 & & 252 & 121 \\
\hline & \multirow{2}{*}{$\mathrm{C}$} & 113 & 174 & 99 & 183 & 213 & 141 & 122 & 209 & 248 & 121 \\
\hline & & 117 & 182 & 99 & 183 & 215 & 143 & 132 & 209 & 252 & 121 \\
\hline \multirow{4}{*}{4} & \multirow{2}{*}{$\mathrm{H}$} & 115 & 154 & \multirow[b]{2}{*}{$\mathrm{nc}$} & 183 & 215 & 141 & 130 & 201 & 256 & 121 \\
\hline & & 115 & 162 & & 189 & 215 & 143 & 134 & 215 & 256 & 121 \\
\hline & \multirow{2}{*}{$\mathrm{C}$} & 115 & 154 & 93 & 183 & 215 & 141 & 130 & 201 & 256 & 121 \\
\hline & & 115 & 162 & 99 & 189 & 215 & 143 & 134 & 215 & 256 & 121 \\
\hline \multirow{4}{*}{5} & \multirow{2}{*}{$\mathrm{H}$} & 113 & 148 & 81 & 181 & 213 & 133 & 130 & 199 & 248 & 121 \\
\hline & & 113 & 152 & 99 & 191 & 213 & 141 & 134 & 207 & 252 & 121 \\
\hline & \multirow{2}{*}{ C } & 113 & 148 & 81 & 181 & 213 & 133 & 130 & 199 & 248 & 121 \\
\hline & & 113 & 152 & 99 & 191 & 213 & 141 & 134 & 207 & 252 & 121 \\
\hline \multirow{4}{*}{6} & \multirow{2}{*}{$\mathrm{H}$} & 113 & 140 & 81 & 189 & 215 & 133 & 124 & 207 & 248 & 121 \\
\hline & & 113 & 148 & 99 & 191 & 215 & 133 & 134 & 207 & 252 & 121 \\
\hline & \multirow{2}{*}{$\mathrm{C}$} & 113 & 140 & 81 & 189 & 215 & 133 & 124 & 207 & 248 & 121 \\
\hline & & 113 & 148 & 99 & 191 & 215 & 133 & 134 & 207 & 252 & 121 \\
\hline
\end{tabular}

H: hair; C: carcass; nc: not considered.

of microsatellites and Dr. Ana Domínguez Sanjurjo of the Universidad de Oviedo for sending the DNA reference samples.

\section{RESUMEN}

Implementación de un sistema de trazabilidad molecular para la carne bovina basado en marcadores microsatélites. Ricardo Felmer D. ${ }^{\text {* }}$, Boris Sagredo D. ${ }^{2}$, Renato Chávez R. ${ }^{1,3}$, Sergio Iraira H. ${ }^{2}$, Carolina Folch M. ${ }^{2}$, Lorena Parra G. ${ }^{1}$, Adrián Catrileo S. ${ }^{1}$, y Manuel Ortiz L. ${ }^{4}$. La trazabilidad de productos de origen animal ha adquirido gran relevancia como un elemento de seguridad ante las crisis alimentarias ocurridas a partir de mediados de los noventa en países de la Comunidad Europea. Esto ha reforzado la gestión de calidad en productos pecuarios, surgiendo la trazabilidad como la principal herramienta para disminuir los riesgos de seguridad y calidad de los productos que demandan los consumidores de países desarrollados. La aplicación práctica de un sistema de trazabilidad de la carne bovina basado en marcadores moleculares, requiere la elección de microsatélites y optimizar los métodos de muestreo y análisis de ADN. En este trabajo se implementó un sistema de trazabilidad de carne bovina basado en un panel de 10 marcadores microsatélites. Se evaluaron diferentes muestras biológicas como pelo, sangre, tejido y carne de la canal, encontrándose que las muestras de pelo fueron las más idóneas por su facilidad de obtención, manipulación y costo de almacenamiento, mientras que la carne de la canal fue la contramuestra más adecuada, pudiendo obtenerse fácilmente en el frigorífico. El sistema se evaluó en una planta de procesamiento de carne, confirmando con un $100 \%$ de certeza la trazabilidad de 150 muestras de pelo con sus respectivas canales, demostrando la confiabilidad del método desarrollado. El sistema evaluado puede ser un importante aporte al sector pecuario del país pues permite garantizar el origen de los productos bovinos y puede ser utilizado como herramienta certificadora de la trazabilidad convencional, aumentando la competitividad y generando mayor confianza en el consumidor.

Palabras clave: trazabilidad, microsatélites, carne, identificación individual. 


\section{LITERATURE CITED}

Bedoya, G., L. Carvajal, N. Bermúdez, L. Fernando, M. Márquez, S. Davies, et al. 2001. Estructura molecular y poblacional del ganado criollo colombiano. Rev. Col. Cienc. Pec. 14:109-120.

Blott, S., J. Williams, and C. Haley. 1999. Discriminating among cattle breeds using genetics markers. Heredity 82:613-619.

Botstein, D., R. White, M. Skolnick, and R.W. Davis. 1980. Construction of a genetic linkage map in man using restriction fragment length polymorphism. Am. J. Hum. Gen. 32:314-331.

Caja, G., R. Nehring, and C. Conill. 2000. Identifying livestock with passive transponders. Meat Automation 1:18-21.

Chávez, R., R. Felmer, A. Catrileo, B. Sagredo, S. Iraira, y C. Folch. 2004. Evaluación de microsatélites bovinos para la implementación de un sistema de trazabilidad molecular de la carne bovina. p. 151-152. In XXIX Reunión Anual de SOCHIPA, Villarrica. 13-15 de octubre 2004. Sociedad Chilena de Producción Animal (SOCHIPA), Temuco, Chile.

Conill, C., G. Caja, R. Nehring, and R. Ribó. 2002. The use of passive injectable transponders in fattening lambs from birth to slaughter: Effects of injection position, age, and breed. J. Anim. Sci. 80:919-925.

Council of the European Communities. 2000. Regulation (EC) No. 1760/2000 of the European Parliament and of the Council of 17 July 2000 establishing a system for the identification and registration of bovine animals and regarding the labeling of beef and beef products and repealing Council Regulations (EC) No. 820/97. Off. J. Eur. Communities L204:1-10.

Cunningham, E., and C. Meghen. 2001. Biological identification systems: genetic markers. Rev. Sci. Tech. Off. Int. Epiz. 20:491-499.

Felmer, R., R. Chávez, A. Catrileo, y C. Rojas. 2006. Tecnologías actuales y emergentes para la identificación animal y su aplicación en la trazabilidad animal. Arch. Med. Vet. 38:197-206.

Fernández, R. 2002. Trazabilidad alimentaria. Una herramienta decisiva para la seguridad y la protección de los consumidores. Distribución y Consumo $\mathrm{N}^{\mathrm{o}} 62$ (Marzo-abril). p. 5-10.

Folch, C., B. Sagredo, S. Iraira, R. Felmer, A. Catrileo, y R. Chávez. 2004. Avances en el desarrollo de un método de identificación molecular para evaluar la trazabilidad en una planta de procesamiento de carne bovina de la X Región de Chile. p. 153-154. In XXIX Reunión Anual de SOCHIPA, Villarrica. 13-15 de octubre 2004. Sociedad Chilena de Producción Animal (SOCHIPA), Temuco, Chile.
Lodish, H., D. Baltimore, A. Berk, S. Zipursky, P. Matsudaira, and J. Darnell. 1995. Molecular cell biology. 1344 p. $3^{\text {rd }}$ ed. Scientific American Books, New York, USA.

Masahiko, S., O. Yamakita, H. Shin-ichi, K. Yuji, A. Hiroko, S. Naoki, and K. Ryo. 2001. A horse identification system using biometrics. Syst. Comput. Jpn. 32:12-23.

Mathias, M., B. Sagredo, and J. Kalazich. 2007. Uso de marcadores SSR para identificación de germoplasma de papa en el programa de mejoramiento de INIA de Chile. Agric. Téc. (Chile) 67:3-15.

Mujica, F. 2005. Diversidad, conservación y utilización de los recursos genéticos animales en Chile. Boletín INIA $\mathrm{N}^{\circ} 137.124 \mathrm{p}$. Instituto de Investigaciones Agropecuarias, Centro Regional de Investigación Remehue, Osorno, Chile.

Panaccio, M., and A. Lew. 1991. PCR based diagnosis in the presence of $8 \%(\mathrm{v} / \mathrm{v})$ blood. Nucleic Acids Res. 19:1151.

Ribó, O., C. Korn, U. Meloni, M. Cropper, P. De Winne, and M. Cuype. 2001. IDEA: a large-scale project on electronic identification of livestock. Rev. Sci. Tech. Off. Int. Epiz. 20:426-436.

SAG. 2006. Procedimientos generales del Programa Oficial de Trazabilidad Sanitaria Animal. Disponible en http://www.trazabilidad.sag.gob.cl (Leído octubre 2006).

Tautz, D. 1989. Hypervariability of simple sequences as a general source for polymorphic DNA markers. Nucleic Acids Res. 17:6463-6471.

Tessier, C., J. David, P. This, J.M. Boursiquot, and A. Charrier. 1999. Optimization of the choice of molecular markers for varietal identification in Vitis vinifera L. Theor. Appl. Genet. 98:171-177.

Vázquez, F., T. Pérez, F. Ureña, E. Gudín, J. Albornoz, and A. Domínguez. 2004. Practical application of DNA fingerprinting to trace beef. J. Food Prot. 67:972-979.

Visscher, P.M., J. Woolliams, D. Smith, and J. Williams. 2002. Estimation of pedigree errors in the UK dairy population using microsatellite markers and the impact on selection. J. Dairy Sci. 85:2368-75.

Zamora, M., R. Ginés, J.M. Afonso, M. Reig, L. García, y J. Zamorano. 2004. Caracterización genética de la raza bovina Canaria utilizando microsatélites: Estudio preliminar. Arch. Latinoam. Prod. Anim. 12:12-15. 